\title{
ANALISIS KETERBUKAAN INFORMASI PUBLIK DALAM KAJIAN TEORI HAK ASASI MANUSIA DAN EFEKTIVITAS HUKUM
}

Oleh:

\author{
Toni, S.H., M.H.
}

\begin{abstract}
The openness of public information is part of the human rights related to personal development rights guaranteed in legislation. This study was conducted to find out the legal events when examined from the theory of human rights and the effectiveness of the law. The results of this study are openness of public information is a human right is not supernatural guaranteed in the basic law and the rules of corporate governance and implementation in the field has not been fullest because it influenced several factors namely: the difference between the understanding of perception public body with the applicant information public body that held the rule of State secrets and the lack of synchronization between the standards and regulations of public information disclosure with State secrets.
\end{abstract}

Keywords : The openness of public information, human rights and the effectiveness of the law

\section{A. PENDAHULUAN}

Hak Asasi Manusia, ${ }^{1}$ bersumber dari Allah Yang Maha Esa dan harus dijunjung tinggi, jika dilihat dari pendekatan kekuasaan maka kekuasaan pemerintah (negara dalam arti sempit) yang diberi kewenangan untuk melindungi dan memuliakan hak-hak azasi warga negaranya.

Jaminan dan perlindungan hak asasi manusia di Indonesia tertuang dalam Konstitusi Negara Kesatuan Republik Indonesia

*Dosen Tetap Fakultas Hukum Universitas Bangka Belitung.

${ }^{1}$ Hak Asasi Manusia merupakan hak kodrati manusia sebagai mahkluk ciptaan Tuhan Yang Maha Esa. Istilah Hak Asasi Manusia (HAM) sering diistilahkan sebagai Human Rights. sebagaimana diatur dalam Pasal 28A sampai dengan Pasal 28J, artinya jaminan dan upaya perlindungan hak azasi manusia oleh negara diletakkan pada sumber hukum tertulis yang tertinggi dalam sistem ketatanegaraan negara Indonesia.

Sedangkan dalam landasan operasional pelaksanaannya diatur dalam Undang-Undang Nomor 39 Tahun 2009 tentang Hak Asasi Manusia, yang meliputi 10 (sepuluh) golongan Hak Asasi Manusia, yakni:
a. Hak untuk hidup;
b. Hak untuk berkeluarga dan melanjutkan keturunan;
c. Hak mengembangkan diri; 
d. Hak memperoleh keadilan;

e. Hak atas kebasan pribadi;

f. Hak atas rasa aman;

g. Hak atas kesejahteraan;

h. Hak turut serta dalam pemerintahan;

i. Hak wanita; dan

j. Hak anak.

Lingkup kajian ini terfokus pada hak mengembangkan diri (Bahasa Inggris: rights to develop themselves). Dalam Kamus Besar Bahasa Indonesia (KBBI), hak mengembangkan diri merupakan hak dari setiap orang untuk menjadikan diri lebih maju, baik pikirannya maupun pengetahuannya. ${ }^{2}$ Lebih spesifik lagi, yakni hak mencari, memperoleh, memiliki, menyimpan, mengolah dan menyampaikan informasi dengan menggunakan segala jenis sarana yang tersedia. Hak tersebut merupakan pengolongan hak mengembangkan diri dalam landasan operasional Undang-Undang Nomor 39 Tahun 1999 sebagaimana diatur dalam ketentuan Pasal 11 sampai dengan Pasal 16.

Menilik lebih jauh dilihat dari ciri negara hukum salah satunya adalah menjamin dan melindungi hak asasi manusia, kepastian hukum dalam perlindungan hak memperoleh

${ }^{2}$ Departemen Pendidikan dan Kebudayaan, Kamus Besar Bahasa Indonesia, Balai Pustaka, Jakarta, 1989, hlm. 414. informasi terlihat sinkron dengan Undang-Undang Nomor 14 Tahun 2008 tentang Keterbukaan Informasi Publik. Berarti manusia sebagai orang perorangan yang merupakan salah satu komponen publik berhak mendapatkan akses informasi dari negara pada umumnya dan penyelenggara pemerintahan pada khususnya. Undang-Undang Nomor 14 Tahun 2008 tentang Keterbukaan Informasi Publik pada Pasal 7 ayat (1) menentukan, bahwa setiap Badan Publik wajib menyediakan, memberikan dan/ atau menerbitkan Informasi Publik yang berada di bawah kewenangannya kepada Pemohon Informasi Publik, selain informasi yang dikecualikan sesuai dengan ketentuan. ${ }^{3}$

Berdasarkan uraian tersebut di atas, maka rumusan pokok permasalahan dalam penelitian ini adalah untuk menelaah dan mengkaji bagaimanakah keterbukaan informasi publik dalam kajian teori hak asasi manusia dan efektivitas hukum?

\section{B. METODE PENELITIAN}

Metode yang digunakan dalam penelitian ini adalah yuridis normatif, yakni normatif yang mengkaji

${ }^{3}$ http://culniz.blogspot.co.id/2012/05/pema nfaatan-e-goverment-bagi-pelayanan.html 
pelaksanaan atau implementasi ketentuan hukum positif (perundangundangan), di samping itu penelitian ini termasuk juga dalam penelitian kepustakaan (library research). Adapun pendekatan kajian yang digunakan adalah pendekatan teoretis, yakni pendekatan yang menelaah dan meneliti peristiwa konkrit dengan teori-teori yang relevan.

\section{PEMBAHASAN}

Informasi menjadi komponen yang sangat vital di era modern saat ini, faktor globalisasi juga mempengaruhi dalam perkembangan kebutuhan hidup manusia yang terus meningkat dan berkembang termasuk juga kebutuhan akan informasi yang berdampak pada pengembangan kualitas diri pribadi dan organisasi, maka informasi disini dipandang sangat urgen dan vital sebagai salah satu sarana pengembangan.

Dalam kehidupan berbangsa dan bernegara, juga tidak terlepas dari pengaruh vital informasi khususnya, yang berhubungan dengan layanan publik, maka prinsip transparansi dan akuntabilitas menjadi prinsip dasar dalam menjalankan badan hukum, khususnya badan hukum publik, karena jika hal tersebut jauh dari keterbukaan dan kecilnya pemahaman, serta bertentangan dengan prinsip dasar tersebut, maka dikhawatirkan akan menimbulkan keresahan dan tidak menutup kemungkinan akan menguak dan berujung pada konflik sosial.

Lembaga eksekutif, lembaga legislatif, dan lembaga yudikatif merupakan lembaga yang menjalankan layanan publik dengan beberapa kreteria, meliputi dana operasional bersumber dana penyelenggaraan dari Anggaran Pendapatan Belanja Negara (APBN) atau Anggaran Pendapatan Belanja Daerah (APBD) maupun sumbangan masyarakat dalam dan luar negeri. Lembaga-lembaga tersebut adalah lembaga yang berbentuk organisasi publik yang kewajiban dalam penyelenggara negara yang disebut juga badan publik diamanahkan dalam Undang-Undang Nomor 14 Tahun 2008 tentang Keterbukaan Informasi Publik.

Sementara, pihak yang membutuhkan informasi disini disebut sebagai pemohon informasi publik merupakan warga negara atau badan hukum yang mengajukan permintaan informasi kepada badan publik. Adapun Tujuan dibentuknya aturan pelaksana hak mencari, memperoleh, memiliki, menyimpan, 


\author{
mengolah dan menyampaikan \\ informasi dengan menggunakan \\ segala jenis sarana yang tersedia, \\ antara lain:
}

a. menjamin hak warga negara untuk mengetahui rencana pembuatan kebijakan publik, program kebijakan publik, dan proses pengambilan keputusan publik, serta alasan pengambilan suatu keputusan publik;

b. mendorong partisipasi masyarakat dalam proses pengambilan kebijakan publik;

c. meningkatkan peran aktif masyarakat dalam pengambilan kebijakan publik dan pengelolaan Badan Publik yang baik;

d. Mewujudkan penyelenggaraan negara yang baik, yaitu yang transparan, efektif dan efisien, akuntabel serta dapat dipertanggungjawabkan;

e. Mengetahui alasan kebijakan publik yang mempengaruhi hajat hidup orang banyak;

f. Mengembangkan ilmu pengetahuan dan mencerdaskan kehidupan bangsa; dan/atau

g. Meningkatkan pengelolaan dan pelayanan informasi di lingkungan Badan Publik untuk menghasilkan layanan informasi yang berkualitas. ${ }^{4}$

Sedangkan informasi yang dikecualikan dalam Undang-Undang KIP, antara lain:

\footnotetext{
${ }^{4}$ www.wikipedia.com
}

a. Informasi Publik yang apabila dibuka dan diberikan kepada Pemohon Informasi Publik dapat menghambat proses penegakan hukum;

b. Informasi Publik yang apabila dibuka dan diberikan kepada Pemohon Informasi Publik dapat mengganggu kepentingan perlindungan hak atas kekayaan intelektual dan perlindungan dari persaingan usaha tidak sehat;

c. Informasi Publik yang apabila dibuka dan diberikan kepada Pemohon Informasi Publik dapat membahayakan pertahanan dan keamanan negara;

d. Informasi Publik yang apabila dibuka dan diberikan kepada Pemohon Informasi Publik dapat mengungkapkan kekayaan alam Indonesia;

e. Informasi Publik yang apabila dibuka dan diberikan kepada Pemohon Informasi Publik, dapat merugikan ketahanan ekonomi nasional;

f. Informasi Publik yang apabila dibuka dan diberikan kepada Pemohon Informasi Publik, dapat merugikan kepentingan hubungan luar negeri;

g. Informasi Publik yang apabila dibuka dapat mengungkapkan isi akta otentik yang bersifat pribadi dan kemauan terakhir ataupun wasiat seseorang;

h. Informasi Publik yang apabila dibuka dan diberikan kepada Pemohon Informasi Publik dapat mengungkap rahasia pribadi;

i. Memorandum atau surat-surat antar Badan Publik atau intra Badan Publik, yang menurut sifatnya dirahasiakan kecuali atas putusan Komisi Informasi atau pengadilan; 
j. Informasi yang tidak boleh diungkapkan berdasarkan Undang-Undang. ${ }^{5}$

Sementara jika hak asasi manusia dilihat dari perspektif hukum administrasi negara, maka terdapat 3 (tiga) pendekatan, yaitu:

a. Pendekatan terhadap kekuasaan pemerintah, yang menekankan pada kekuasaan pemerintah sebagai fokus hukum administrasi.

b. Pendekatan terhadap hak asasi manusia, pendekatan baru dalam hukum administrasi yang mulai dikembangkan oleh Inggris, penekanannya adalah perlindungan terhadap hak-hak asasi dan asas-asas pemerintahan yang baik.

c. Pendekatan fungsionaris, pendekatan yang melengkapi pendekatan-pendekatan di atas, yang mana lebih menekankan kepada pejabat publik yang menjalani kekuasaan negara. ${ }^{6}$

Dari beberapa pendekatan tersebut, jika dikaitkan dengan hak memperoleh informasi, maka terlihat jelas, bahwa ada beberapa norma dasar bagi prilaku aparat (badan publik), yaitu:

a. Sikap Melayani

Dalam prilaku tersebut, badan publik berkaitan dengan layanan publik merupakan implementasi perlindungan

\footnotetext{
${ }^{5}$ Ibid.

${ }^{6}$ Muladi (Editor), Hak Azasi Manusia, Refika Aditama, Jakarta, 2005, hlm. 65.
}

HAM, khususnya hak untuk mengembang diri dalam bentuk hak atas informasi.

b. Terpecaya

Dengan keterbukaan publik atas segala informasi, maka akan terlihat norma dasar prilaku badan publik yang menggambarkan

pemerintahan yang baik dalam pemenuhan kebutuhan informasi dari para pemohon informasi. $^{7}$

Dilihat dari tujuan dan pengecualian tertentu dalam pelaksanaan keterbukaan informasi publik, terlihat jelas batasan dan standar-standar tertentu dalam mengungkapkan rasa ingin mengetahui dalam mendapatkan informasi yang dibutuhkan untuk pengembangan diri, padahal dalam konteks hak asasi manusia dapat dipahami, bahwa hak mengembangkan diri dalam substansi hak mencari, memperoleh, memiliki, menyimpan, mengolah dan menyampaikan informasi dengan menggunakan segala jenis sarana yang tersedia dilihat dari pendapat Joel Feinberg adalah dianggap sebagai hak-hak moral umum menyangkut sesuatu yang secara fundamental penting dan dimiliki secara setara oleh semua orang sebagai anggota masyarakat, tanpa

\footnotetext{
${ }^{7}$ Ibid., hlm. 66.
} 
syarat dan tidak dapat diganggu gugat, entah hak-hak ini termasuk dalam kategori "moral" dalam arti tegas dan dianggap sebagai persoalan terbuka yang mesti diselesaikan melalui argumentasi, dan bukan melalui definisi. $^{8}$

Dari penjelasan di atas, dapat dilihat ada 3 (tiga) unsur yang mendasar, yakni:

a. Sebagai hak moral;

b. Dipunyai oleh semua orang, dan

c. Tidak dapat diganggu gugat.

Dari ketiga unsur tersebut, pada unsur tidak dapat diganggu gugat mengandung arti, bahwa dalam implementasi hak untuk mendapatkan informasi tidak dapat dihalanghalangi, dibatalkan, disembunyikan dengan alasan apapun, termasuk negara sebagai organisasi yang menjalankan kekuasaan, karena pengaturan Hak Asasi Manusia yang dianggap hak mutlak dilindung sebagaimana yang tersirat dalam konstitusi Negara Kesatuan Republik Indonesia, Undang-Undang Dasar Tahun 1945.

Apabila dikaji lebih mendalam, bahwa hak mencari, memperoleh, memiliki, menyimpan, mengolah dan

${ }^{8}$ Salim HS., dan Erlies SN, Penerapan Teori Hukum, Buku ke-3, Rajawali Press, Jakarta, 2016, hlm. 257. menyampaikan informasi ditinjau dari beberapa teori yang menganalisis tentang hak asasi manusia yang meliputi:

a. Teori Hak-hak Kodrat

Natural right theory dalam Bahasa Inggris, menurut Andrey Sujatmoko dalam buku Penerapan Teori Hukum pada Penelitian Disertasi dan Tesis karangan Salim HS dan Erlies HN tertulis, bahwa teori ini merupakan teori yang mengananisis Hak Asasi Manusia dari hak-hak alamiah dikonsepsikan berdasarkan atas pemberian Tuhan berdasarkan hukum kodrat, dan menurut teori hak-hak kodrati dipahami, bahwa HAM merupakan hak-hak yang dimiliki semua orang setiap saat di semua tempat oleh karena manusia dilahirkan sebagai manusia. Hak mencari, memperoleh, memiliki, menyimpan, mengolah dan menyampaikan informasi dalam hal ini keterbukaan informasi publik jika dilihat dari hak-hak kodrati, maka berarti kodratlah yang menciptakan dan mengilhami akal budi dan pendapat manusia, setiap manusia terlahir dengan hak-hak 
alamiah dan hak itu dimiliki manusia dalam keadaan alamiah dan digunakan sebagai alat dalam kehidupan bermasyarakat. Artinya, hak untuk memperoleh informasi dalam pengembangan diri merupakan takdir Tuhan karena kodrat manusia yang melekat dalam diri manusia ketika dilahirkan. ${ }^{9}$

b. Teori Positivisme

Dalam teori ini, hak asasi manusia dipahami dari sudut hukum negara yang telah ditetapkan dalam hukum negara. Menurut Scott Davison, dalam positivisme suatu hak harus berasal dari sumber yang jelas, seperti peraturan perundangundangan atau konstitusi negara. Artinya essensi hak asasi manusia tidak hanya bersumber dari Tuhan sebagai hak kodrati, tetapi juga harus diturunkan dari hukum negara. ${ }^{10}$ Konteks keterbukaan informasi publik, sebagai pelaksana/operasional hak mencari, memperoleh, memiliki, menyimpan, mengolah dan menyampaikan informasi dalam konstitusi adalah pengagung-an dari negara yang

${ }^{9}$ Ibid., hlm. 274.

${ }^{10}$ Ibid. termaktub dalam hukum dasar dan dioperasionalkan dalam undang-undang sebagai wujud karakteristik negara hukum.

c. Teori Universalisme

Menurut Mashood

A.

Baderin dalam bukunya Hukum Internasional Hak Asasi Manusia dan Hukum Islam, bahwa Teori yang berangkat dari konsep universalisme moral dan kepercayaan akan keberadaan kode-kode moral universal yang melekat pada seluruh umat manusia, kebenaran moral yang bersifat lintas budaya dan lintas sejarah dapat diidentifikasikan secara rasional. Implementasi hak mencari, memperoleh, memiliki, menyimpan, mengolah dan menyampaikan informasi dalam tataran upaya yang merupakan cara pengembangan diri individu atau kelompok merupakan hasrat alamiah yang bersifat umum universal dimiliki setiap manusia lintas batasan tempat dan waktu, termasuk dalam sistem pemerintahan yang berhubungan dengan administrasi publik. ${ }^{11}$

Karena sifat universal hak asasi manusia, maka dalam 
lingkup administrasi negara berkaitan langsung antara hak asasi dengan konsep good governance. Hal ini jelas terlihat dari administrasi publik, apabila administrasi publik dilaksanakan dengan baik, maka good governance yang dicita-citakan merupakan implementasi dari perlindungan dan jaminan terhadap hak asasi manusia dan badan publik sebagai "motor" utama pemerintahan yang sangat berperan dalam mewujudkan good governance di Indonesia. ${ }^{12}$

Dalam mewujudkan pemerintahan yang baik dari segi layanan publik, khususnya layanan informasi tanpa batas sebagai mana dijamin dalam konstitusi dan undang-undang hak asasi manusia merupakan wujud jaminan Hak asasi manusia yang diberikan negara kepada rakyatnya.

d. Teori Relativisme Budaya

Hak asasi manusia dipahami bersumber dari watak dasar manusia, dan berpijak pada moralitas inilah hakikat dasar dari teori ini. Oleh karena itu, hak

\footnotetext{
${ }^{12}$ Mohammad Ryan Bakry, "Implementasi HAM dalam Konsep Good Governance di Indonesia", Tesis, Megister Hukum Program Pasca Sarjana FH UI, Jakarta, 2010, hlm. 6.
}

asasi manusia tidak dapat ditafsirkan tanpa penghormatan terhadap perbedaan-perbedaan budaya masyarakat, dapat pula dikatakan bahwa hak-hak dan aturan-aturan moralitas dikodekan dalam dan karena itu bergantung pada konteks budaya masing-masing. ${ }^{13}$

Ketika peradaban manusia terus berkembang seiring dengan perkembangan zaman, maka akan terbentuk pula budaya yang dipengaruhi faktor globalisasi dan teknologi, sehingga informasi menjadi vital perannya. Negara dalam arti sempit adalah administrator publik dalam menjalankan kekuasaannya, maka dituntut dengan pelayanan yang bersifat baik, efektif dan efisien. Pada persoalan ini, yang dibutuhkan adalah transparansi dan bertanggung jawab. Ketika publik menuntut transparansi atas kekuasaan/kedaulatan yang telah dititipkan, maka menjadi hak dasar pemberi kedaulatan untuk mempertanyakan itu. Artinya dalam teori relativisme budaya, hak asasi manusia dalam era reformasi dan menjunjung tinggi

\footnotetext{
${ }^{13}$ Ibid., hlm. 26.
} 


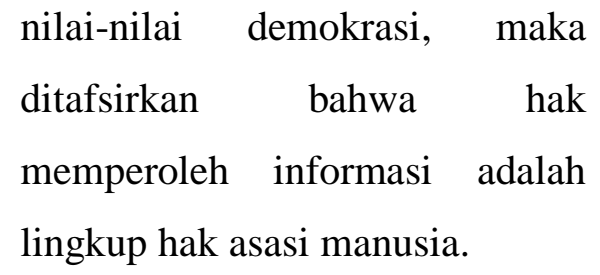

Sebagai contoh, Swedia, negara pertama yang mengadopsi undang-undang hak atas informasi pada tahun 1766, kemudian 90 (sembilan puluh) negara telah mengadopsi undangundang serupa, yang mayoritas disini adalah negara-negara demokrasi, hampir diseluruh dunia mengadopsi undangundang tersebut termasuk Indonesia. $^{14}$ Karena dianggap urgen dalam upaya perlindungan HAM, maka relativisme budaya suatu negara pasti membutuhkan legalitas pengakuan terhadap perlindungan hak atas informasi.

Untuk melihat efektivitas aturan hukum dalam hal ini adalah Undang-Undang Nomor 14 Tahun 2008 tentang Keterbukaan Informasi Publik, maka diuji dengan teori efektivitas hukum. Mengkualifikasikan dari pendapat Anthony Allot tentang efektivitas hukum, maka

\footnotetext{
${ }^{14}$ Center For Law and Democracy \& AJI, Bagaimana Pemohon Bisa Memanfaatkan Hak atas Informasi, 2011, hlm. 7.
}

disimpulkan dalam kajian efektivitas hukum menekankan pada 3 (tiga) fokus bahasan, yang meliputi: keberhasilan dalam pelaksanaan, kegagalan dalam pelaksanaannya, dan faktorfaktor yang mempengaruhi. ${ }^{15}$

a. Keberhasilan dalam Pelaksanaannya

Berkaitan erat dengan pemenuhan prinsip dasar negara demokrasi, dalam hal ini adala kebebasan pers, alasan normatif tentang signifikansi kebebasan pers dalam kehidupan masyarakat pada dasarnya berkaitan pada kehidupan warga masyarakat di ruang publik. Kebebasan pers dapat diartikan di satu pihak sebagai hak warga negara untuk mengetahui (right to know) masalahmasalah publik, dan di pihak lainnya hak warga dalam mengekspresikan pikiran dan pendapatnya (right to expression). Dengan demikan, dasar pikiran mengapa warga harus dijamin haknya untuk mengetahui masalah publik, dan mengapa pula warga 260.

${ }^{15}$ Salim HS., dan Erlies SN., Op. Cit., hlm. 
harus dijamin haknya untuk menyatakan pendapat, perlu ditempatkan dalam prinsip demokrasi yang bertolak dari hak asasi manusia. ${ }^{16}$ Artinya, keberhasilan dari implementasi peraturan tersebut salah satunya terletak pada relevansi kebebasan pers sebagai salah satu prinsip dasar negara demokrasi, karena pers menjadi organisator yang mampu memberi informasi dari faktafakta publik yang didapat dari badan publik dan terbukanya ruang informasi publik dengan pengecualian.

b. Kegagalan dalam Pelaksanaannya

Kesiapan badan publik dalam memberikan informasi masih dipertanyakan dengan interpretasi yang berbeda terhadap informasi itu sendiri. Adanya penolakan badan publik memberikan informasi, yang ditafsirkan bertentangan dengan peraturan perundang-

\footnotetext{
${ }^{16}$ Ashadi Siregar, "Hak Publik Memperoleh Informasi dan Kebebasan Pers", Makalah, Disampaikan pada Seminar Kebebasan Memperoleh Informasi, Lembaga Studi Perubahan Sosial Bekerjasama dengan Koalisi untuk Kebebasan Informasi, Surabaya, 20 November 2001.
}

undangan rahasia negara atau lainnya. Akibat penolakan badan publik, maka munculnya sengketa informasi publik. Komisi Informasi Pusat (KIP), dari tahun 2010 hingga 2014 telah menerima permohonan penyelesaian sengketa informasi publik sebanyak 2.549 permohonan pelanggaran konstitusional hak asasi manusia, karena banyaknya penolakan yang menimbulkan sengketa informasi publik. ${ }^{17}$

c. Faktor-faktor yang Mempengaruhi

1) Badan Publik

Badan publik yang tersandera oleh peraturan perundang-undangan rahasia negara yang ditafsirkan definisi tetapi bukan dengan argumentasi, yang mestinya pemahaman informasi publik dengan mengedepankan HAM bukan hal-hal lainnya dan cenderung ego sektoal dalam menjalankan kewenangannya. Psikologis organisasi keterbukaan informasi

${ }^{17}$ http://www.varia.id/2015/05/01/permoho nan-penyelesaian-sengketa-informasi-ke-kipmeningkat/\#ixzz48WBev1tY, diakses 15 Februari 2016. 
dipahami sebagai ketakutan

"membuka aib"

2) Sinkronisasi

Peraturan

Perundang-undangan

Dalam hal ini, penetapan standar batasan informasi publik dan rahasia negara belum sinkron, hingga melahirkan multi tafsir di antara subjek hukum yang berhubungan dengan informasi publik.

\section{PENUTUP}

Keterbukaan informasi publik dalam kajian teori hak asasi manusia dan efektivitas hukum, dapat disimpulkan bahwa:

1. Keterbukaan informasi publik merupakan hak asasi yang melekat secara kodrati, memiliki legalitas yang tinggi dalam konstitusi, dipahami sama oleh negara-negara modern, lahir dari realita budaya yang berkembang.

2. Tingkat efektivitas dalam pelaksanaan aturan belum maksimal. Hal ini dipengaruhi beberapa faktor, yakni: perbedaan persepsi pemahaman antara badan publik dengan pemohon informasi; badan publik yang tersandera aturan rahasia negara dan tidak adanya sinkronisasi standar antara peraturan perundang-undangan keterbukaan informasi publik dengan rahasia negara.

\section{E. DAFTAR PUSTAKA}

Ashadi Siregar. 2001. "Hak Publik Memperoleh Informasi dan Kebebasan Pers". Makalah. Disampaikan pada Seminar Kebebasan Memperoleh Informasi, Lembaga Studi Perubahan Sosial Bekerjasama dengan Koalisi untuk Kebebasan Informasi, Surabaya, 20 November 2001.

Center For Law and Democracy \& AJI. 2011. Bagaimana Pemohon Bisa Memanfaatkan Hak atas Informasi.

Departemen Pendidikan dan Kebudayaan. 1989. Kamus Besar Bahasa Indonesia. Balai Pustaka, Jakarta.

Mohammad Ryan Bakry. 2010. "Implementasi HAM dalam Konsep Good Governance di Indonesia". Tesis. Megister Hukum Program Pasca Sarjana FH UI, Jakarta.

Muladi (Editor). 2005. Hak Azasi Manusia. Refika Aditama, Jakarta.

Republik Indonesia. Undang-Undang Nomor 14 Tahun 2008 Tentang Keterbukaan Informasi Publik (Lembaran Negara Republik Indonesia Tahun 2008 Nomor 61, Tambahan Lembaran Negara Republik Indonesia Nomor 4846).

Salim HS., dan Erlies SN. 2016. Penerapan Teori Hukum. Buku 
ke-3. Rajawali Press, Jakarta, 2016.

http://culniz.blogspot.co.id/2012/05/pema nfaatan-e-goverment-bagipelayanan.html

http://www.varia.id/2015/05/01/permoho nan-penyelesaian-sengketainformasi-ke-kipmeningkat/\#ixzz48WBev1tY, diakses 15 Februari 2016.

$\underline{\text { www.wikipedia.com }}$ 